\title{
Unequal citizenship in unequal cities: Participatory urban governance in post-apartheid South Africa
}

\section{Dr Charlotte Lemanski}

\author{
Department of Geography \\ University of Cambridge \\ Downing Place, CB2 3EN
}

\author{
Senior Research Fellow \\ Department of Geography \\ University of Johannesburg
}

Email: c1152@cam.ac.uk

\section{Acknowledgements}

This research was funded by a Royal Geographical Society Small Research Grant, and also benefitted from involvement in the CORUS project, The voice of the urban poor in city governance, coordinated by Prof Claire Benit-Gbaffou at the University of Witwatersrand.

\begin{abstract}
Participatory governance has become a mainstream feature of city management, endorsed by governments and aid agencies as a platform for state-civil society engagement. Despite this popularity, criticisms are rife, focusing on agency problems of implementation alongside fundamental concerns related to structural power asymmetries. However, remarkably absent from these debates is the active role played by the urban spatial and temporal structural context in shaping citizenship experiences of participatory processes. Based on fieldwork in a electoral ward of Cape Town, South Africa, a geopolitical space that hosts a wide socioeconomic range of citizens, the paper demonstrates how the spatial and temporal landscape of the city is not a neutral technical backdrop for participatory processes, but active in creating and perpetuating inequalities that are institutionalised through processes of participatory governance. This ultimately produces a two-tier form of unequal citizenship.
\end{abstract}

Keywords: Participatory governance; citizenship, Cape Town, South Africa, Urban 


\section{Unequal citizenship in unequal cities: Participatory urban governance in contemporary South Africa}

\section{Introduction}

State-led forms of participation have become normalised components of governing cities over the past twenty years, argued as necessary platforms for information and knowledge exchange between citizens and government. Despite a wealth of criticism regarding implementation, such as the scarcity of active participation (as opposed to informationsharing) and the ease of elite capture to give just two examples, governments and international aid agencies continue to promote participation as the crux of democratic urban governance. Against this backdrop, this research explores how participatory urban governance functions in the context of an extremely unequal Southern city. ${ }^{1}$ Specifically, research highlights how the spatial and temporal landscape of the urban can obstruct rather than assist local democracy. Grounded within international literature on participatory urban governance, this paper uses research undertaken in South Africa to reveal how the institutional (or 'invited' in Cornwall's (2004) terms) state-led spaces of participation so frequently heralded by international aid agencies easily undermine and devalue the voices of (some) citizens by failing to acknowledge the temporal and spatial political geographies onto which they are projected. Temporal in the sense of potentially ignoring and undermining preexisting forms of participation and civil mobilisation, and spatial in entrenching pre-existing inequalities as well as functioning at state-devised spatial scales that are meaningless to citizens.

South Africa's post-apartheid era brought with it great hope for the future, including assumptions that new institutional democracy at the national level would translate into greater involvement in decision-making for citizens at the local level, particularly for those previously marginalised under the apartheid regime (Parnell et al, 2002). Indeed, the postapartheid government has implemented a wide range of participatory schemes. At the municipal scale the flagship Integrated Development Plans (IDPs) are a participatory process whereby the city and its residents meet to collectively agree priority areas for the City's fiveyear budget (in Cape Town this has recently resulted in an agreed focus on jobs, housing, and safety and security). At the neighbourhood scale, the ward committee scheme was established in 2000 to provide a localised space for citizens and the state (via councillors) to communicate about issues related to their local area that can be channelled to sub-council and city structures. It is this space of participatory urban governance that this research examines.

State-initiated participatory mechanisms of governance have been largely ineffective in bringing greater decision-making and influence to citizens (Sinwell, 2010). While technical failings are attributed to problems of agency implementation such as elite capture, there is also widespread critique of the conceptual foundations of the participatory approach, specifically related to power asymmetry (e.g. Cooke and Kothari, 2001). However, it is not merely agency-related problems of implementation and conceptual concerns related to power that are important, but also structural and institutional constraints related to the spatial and historic context in which participatory governance is designed and implemented. Specifically, in an historic context of extreme socio-economic and spatial inequality, implementing a

\footnotetext{
${ }^{1}$ I use the term 'southern city' not to suggest that all cities of the global South share a common identity or history, but to demonstrate the positioning of this work within an emerging body of scholarship arguing the need for theory that is produced from the South (e.g. Parnell and Oldfield, 2014)
} 
model of participatory governance that relies on pre-existing spatial and socio-economic structures has entrenched exclusion and institutionalised a two-tier form of unequal citizenship. Using an example of participatory urban governance in Cape Town, this paper argues that the structural (spatial and historic) backdrop (not merely the human agency within it and the conceptual roots on which it is based) for participatory urban governance plays a crucial role, yet is overlooked in the existing literature. This argument builds on the critique emerging from Lemanski and Marx (2015), that the space of the city is not merely a static container for urban processes (such as poverty, governance, citizenship), but that the spatiality of the city itself plays a dynamic role in creating and perpetuating such processes.

The paper commences by situating the research within broader debates on participatory urban governance, before proceeding to explain the South African context of public participation, particularly the ward forum/committee process within the specific research case study. The two subsequent substantive sections consider the role of spatial scale (in this case, the electoral ward) and temporal blindness (in this case, relying on pre-existing civil society groups) in distorting access to equal citizenship within the ward forum process of participatory urban governance. The third substantive section considers the ways in which a process of participatory urban governance that exists in the context of extreme inequality yet employs pre-existing scales of governance (the electoral ward) and ignores historic capacity (temporal blindness) can entrench and deepen, rather than transform, pre-existing inequalities, and consequently institutionalise two-tier citizenship practices.

\section{Participatory urban governance}

Contemporary interest in urban governance (as opposed to government, as the institutions that make and enforce decisions) reflects a shift towards the inclusion of citizens (alongside other non-state actors) in decision-making processes that affect the urban spaces in which they live and work. Although a global trend, this neo-liberal approach has been specifically promoted in the global South through good governance strategies (UNCHS, 2000). Over the past two decades International Financial Institutions such as the World Bank and the UNDP have required states to work collaborately with civil society via institutions of participatory governance as part of a global re-scaling towards the localisation of democracy (Harpham and Boatang, 1997; Pieterse, 2002; Williams, 2004). Although this decentralisation is typically associated with state withdrawal from service provision, it has also provided the framework for participatory urban governance (Coaffey and Healey, 2003; McEwan, 2003). Particularly in the global South, this localised participatory agenda emerged with expectations that it would provide a voice for the poor, and ultimately secure an inclusive and just city (Heller, 2001; Pieterse, 2002). Participatory urban governance is conceptualised as a multi-actor process involving interaction between various stakeholders; from the formal institutions of government, to business, community groups and citizens; collaborating to make decisions about the allocation of resources within a defined territorial space. However, in practice participatory governance is not a de-centered form of equal power sharing amongst all stakeholders, and has instead been largely state-initiated and managed, described by sociologist Bob Jessop (2001) as "metagovernance" (i.e. the governance of governance)

Despite widespread implementation in cities throughout the world, there is general consensus in the literature that state-led participatory processes fail to translate their idealism, that including citizens and civil society in decision-making creates more just and inclusive cities, into practice. While initial literature on participation was optimistic about its potential to 
serve a dual-purpose in securing more just policies while at the same time empowering social actors, this was followed by more pessimistic accounts of participation's limitations in practice (Coelho and Favareto, 2011). Critical discussion regarding participatory mechanisms was initiated within development studies (e.g. Cooke and Kothari, 2001; Hickey and Mohan, 2004; Williams, 2004), an obvious location given the disciplinary origins of the concept and practice (Chambers 1983), focusing on two key issues. Firstly, an internal critique of the practical implementation of participatory processes, and secondly, a fundamental critique of the power effects of participatory discourse and practice. It is the latter critique that has received most attention in the literature, arguing that participation serves to de-politicise rather than empower participants by legitimising and mainstreaming the voices of those with most power (e.g. Rahnema, 1997, Cooke and Kothari, 2001). This resonates with research within political geography, where Erik Swygedouw (2005) argues that contemporary forms of "governance beyond the state" privilege unelected and potentially unrepresentative actors (citizens and the private sector) within a system designed and managed by the state to meet its own needs rather than those of civil society. Consequently Swygedouw interprets public urban participatory schemes as spaces where citizenship is constrained rather than activated. Similarly, within development studies Cooke and Kothari (2001) argue against revising participatory methods, insisting that the entire project of participation is flawed because it does not challenge structural (e.g. economic and political) inequalities, and is merely a mask for top-down development.

Political anthropologist Andrea Cornwall (2000, 2004a, 2004b) provides greater nuance to these debates by employing a citizen-perspective that categorizes participatory processes as invited or invented depending on the role of the state. Invited spaces are the dominant form of participatory governance discussed in the literature (Sinwell, 2010), representing participative procedures that are externally established, in which citizens are invited to participate - either individually or collectively via civil society organisations (Cornwall, 2004a, 2004b). As these institutional forms of participatory governance are created and managed by the state they are arguably based on the state's normative vision of 'good' citizenship, as well as providing a mechanism for civil society to fill the gaps in service provision left by neoliberal state withdrawal (Miraftab, 2004). In contrast, 'invented spaces' describe grassroots-led forms of political mobilisation through collective action functioning in confrontation (rather than concertation) with authorities (Sinwell, 2010). Recognising the role of the state is crucial in assessing participatory processes, and indeed those countering the de-politicisation debate (e.g. Hickey and Mohan, 2004; Williams, 2004; Sinwell, 2010) agree that while there are structural constraints related to power, participatory approaches can be transformative and empowering if implemented within a process of institutional change. These critical perspectives are particularly noteworthy for introducing the concept of citizenship to debates on participation, and for extending the discussion outside a focus on development projects and aid agencies, to consider other forms of participatory governance.

Contemporary scholarship on citizenship has focused primarily on the active ways in which citizens practice and demonstrate their citizenship, rather than the legal rules within which citizens function, a distinction that Isin and Nielson (2008) label as acts and practices respectively. While scholars demonstrate how citizenship acts can be radically "insurgent" (Holston, 2008) or routinely "ordinary" (Staeheli et al, 2012), most concur that citizenship practices typically negotiate exclusion and marginalisation, particularly in global South contexts of colonial legacy and extreme inequality (Kabeer, 2002). Participatory urban governance demonstrates the combination of citizenship acts and practices, as a space of institutionalised practice that has the potential for citizens to act out their citizenship rights 
and responsibilities. Cornwall and Gaventa (2000) argue that because citizenship is practiced rather than given, urban participatory mechanisms offer a space for citizens to function as active "makers and shapers" in determining the shape of their citizenship activism, rather than as passive "users and choosers" of services. Similarly, Hickey and Mohan (2004, 2005) argue that participatory mechanisms can be transformative if implemented as part of a radical political project whereby participants can exercise their citizenship to challenge structural contexts. Despite these optimistic claims, however, there is widespread recognition that the structural constraints within which participatory mechanisms function have, in practice, resulted in marginalisation and exclusion rather than the extension of citizenship rights for the marginalised (Sinwell, 2010).

In analysing these debates, the role of the urban spatial and temporal structural context in shaping citizenship experiences of participatory processes is rarely considered. While the localised scale of participatory governance is criticised for depoliticising actors, and facilitating elite capture (Benit-Gbaffou and Oldfield, 2011), the specifically urban spatial and temporal context is overlooked. This is particularly problematic in contexts of extreme socio-economic and spatial inequality where the inability of participatory governance procedures to translate idealism into reality is neither an agency problem nor exclusively explained by the structural context (e.g. the state and urban space). Consequently, in analysing a specific space of invited participation, this research considers the role of the state in designing and managing the institutional process of urban participatory governance in the context of a highly unequal city, spatially and temporally.

\section{South Africa: new citizenship, old civil society}

South Africa provides a particularly interesting case study for exploring urban participatory governance for two reasons; firstly, because for the majority of citizens full citizenship rights is relatively new, and secondly, because the post-apartheid South African state has prioritised participatory forms of urban governance.

Under apartheid, cities were exclusively white, while urban movement for the majority black population was restricted spatially and temporally. Furthermore, different population groups engaged with entirely separate state structures, with Black African citizens subject to the rural Bantu Department for Home Affairs, rather than the South African state, translated at the local scale into separate Black and White Local Authorities. Since the demise of apartheid in the early-1990s, all citizens of South Africa have equal rights to vote, to move throughout the city, and to influence and engage with a single united government structure at the local, provincial and national level. Thus, possessing equal and full citizenship rights is something very new for most South Africans. However, the constitutional right to equal citizenship is distorted by South Africa's historic and contemporary socio-economic and spatial inequality, where one person's citizenship and political rights can easily exclude another's.

The post-apartheid government has emphasised a decentralised approach to democratisation to meet the needs of citizens at the local scale, particularly those groups disadvantaged under the apartheid regime (Oldfield, 2002; Parnell et al, 2002; Pieterse, 2002; Ballard et al., 2007). At the city-scale Cape Town's post-2000 'unicity' transformed urban governance from comprising over 50 racially-based local authorities into a single metropolitan authority with a unified tax base (Pieterse, 2002). Alongside state re-scaling has been significant emphasis on public participation processes that 'bring government to the people', particularly in cities 
(Beall et al., 2002; Pieterse, 2002). Indeed, South Africa's progressive constitution, founded on principles of redistributive socialism, outlines a key objectives of local government as "to encourage the involvement of communities and community organisations in the matters of local government" (RSA, 1996). However, in practice a neoliberal market-led approach to public authority has dominated, with the participatory IDP criticised for adopting a managerial and technocratic governance style that is state- rather than citizen-driven, (Heller, 2001; McEwan, 2003; Benit-Gbaffou, 2008a).

A key mechanism for localising citizen participation is the introduction of ward committees in South Africa's municipalities, intended to bridge the gap between local government and citizens, operating as the "arms and feet of state-defined services" (Sinwell, 2010:68). Although legislated by the 1998 Municipal Structures Act, ward committees were only promoted by government following the 2000 municipal re-structuring, as a channel of twoway communication between municipal council and local citizens; encapsulated by then President Mbeki's remark that "these committees, whose members are ordinary workers, play a critical role in ensuring the necessary contact between the people and our institutions of government" (DPLG, 2005). Consequently ward committees are advisory, with no formal legislative function (Pieterse, 2002) and comprise up to ten elected members of the ward who must represent the diversity of interests in the area as well as ensure an equitable gender ratio, and are chaired by the local ward councillor (Municipal Structures Act 1998).

The specifics of implementing ward committees are left to municipalities. Not surprisingly, Cape Town's unusual political arena led to a differentiated ward committee system. Unlike the rest of South Africa, local government in the City of Cape Town demonstrates political plurality, with city leadership shifting between the ANC national ruling party and the DA (Democratic Alliance) opposition party since democracy. However, from 2006 the DA led the city in a multi-party coalition, and since 2011 the DA has outright ruled the city. As a consequence, the City of Cape Town delayed introducing ward committees until the DA were effectively in power, and have been the only municipality to introduce an alternative system, that of ward forums, despite opposition from other scales of (ANC-led) government (Cape Argus 2006; Cape Times 2007). In justifying the launch of ward forums in 2007, City officials cited the ineffectiveness of ward committees in other municipalities, particularly the inability of ten members to adequately represent diversity within wards and the tendency for these small committees to replicate local party political structures (Piper and Deacon, 2008). According to the City of Cape Town Speaker (who has responsibility for ward governance) "in Cape Town, you have the opportunity to have ward forums because we feel it's wider, because we want everybody to participate, we want organized input" (pers comm). Consequently, ward forums are larger and more structured, comprising up to 20 members (excluding public officials), with each member representing a sector (e.g. health, sports, religion, education, business, gender) or geographic area (e.g. neighbourhood) within the ward. Sector representatives must demonstrate membership of a community-based organisation (CBO) that is registered with the sub-council, while geographic representatives require supportive signatures from at least 35 members of their voting district (neighbourhood), of which there are 10-12 per ward. The majority of ward forum members are sector rather than geographic, with the latter perceived an option for citizens lacking sufficient capacity to form a CBO (Sub-Council 19 Manager, pers comm). Ward forums' principle role is to make recommendations to the sub-council on behalf of the ward, with the governance structure visually displayed in Figure One.. Sub-councils are unique to Cape Town, promoted as providing "bringing government closer to the people" in providing a space for citizens to demonstrate their voice beyond the scale of the ward (Buire, 2011). Although ward forums have no direct decision-making powers, their recommendations 
influence sub-council's decisions on expenditure of the R700 $000^{2}$ budget for each ward, although only members representing a CBO can apply for large grants. Essentially, membership of the ward forum ensures indirect access to financial resources, in addition to interaction with the ward councillor at monthly meetings. .

Figure 1: City of Cape Town governance structures (devised by author)

At the time of implementation, the Executive Mayor of Cape Town justified the ward forum system as more inclusive, flexible and representative than the prescriptive geographic requirements of ward committees (Zille, 2007). In particular, Cape Town's mayor argued that ward forum's broader membership base would "help to prevent the Ward Forum members from becoming community gatekeepers ... creating serious obstacles to community engagement" (Zille 2007). Such concerns are well-grounded, given indications that South Africa's ward committees function as political hand-puppets for partisan councillors, reproducing a form of localised clientalism that flourishes in the context of limited accountability (Benit-Gbaffou, 2008b; Oldfield, 2008; Piper and Deacon, 2008). However, whether Cape Town's ward forum system can mitigate these limitations is less clear, particularly given the unequal access to resources between sector and geographic members. This paper explores one ward forum in Cape Town, effectively considering the accuracy of the mayor's statement in analysing how a process of invited participation can produce exclusive and/or inclusive forms of citizenship.

Cape Town's ward forum system provides a contemporary example of institutional participatory urban governance, whereby citizens have been "invited" (Cornwall 2004) by the state to participate. Like most cities in the global South, this participatory process plays out in the context of extreme spatial, social and economic inequality, augmented by South Africa's history of uneven citizenship. The City of Cape Town hosts 111 electoral wards, and the case study for research, Ward 71, has 14,131 registered voters, ${ }^{3}$ comprising a highly diverse range of socio-economic groups living in multiple suburbs, from elite households in highly desirable residences, to low-income households in state-subsidised housing. Fieldwork was undertaken in September 2008 and comprised attending ward forum meetings and conducting semi-structured interviews with council officials at various levels (ward, sub-council and municipality) as well as all members of the ward 71 forum. This time-frame is pertinent because fieldwork was undertaken in an active ward forum at a time when ward forums were still new. This is important because only three years later, in 2011, the ward forum system was replaced by the ward committee system common to the rest of South Africa, due to lack of ward forum take-up across the City. This lack of interest has not been amended by the transition to a ward committee system, with indications that fewer than $15 \%$ of wards had a functioning committee in 2013 (Cape Argus, 2013). This research provides an insight into the initial workings of a public participatory system that was explicitly designed to promote inclusivity.

\section{Structural exclusion: spatial framework}

\footnotetext{
${ }^{2}$ R700 000 was approximately $£ 33800$ in 2015 (www.xe.com) and comprises a R500 000 capital budget and a R200 000 operational budget.

${ }^{3}$ According to the City of Cape Town Demarcation in 2005/2006,

http://www.demarcation.org.za/ward_delimitation/FINAL/gz1/wc/Cape\%20Town.htm
} 
Critiques of participatory urban governance highlight both agency problems of implementation, for example elite capture and manipulation by state actors, alongside an inability to challenge existing structural inequalities. Spatial structures are typically overlooked, presumably because of assumptions that they are technical rather than political. However, in the context of extreme historically-entrenched spatial inequality, the geopolitical framework for implementing participatory governance plays a crucial role in mediating access to citizenship. While it is axiomatic that a participatory process devised by the state will promote a statist agenda and vision (ie. of both participatory governance and citizenship) and that state actors (e.g. local politicians) and powerful citizens will direct the process to suit their interests, the role played by spatial frameworks in potentially obstructing local democracy is less obvious and therefore easily overlooked.

Cape Town's state-led forms of participatory governance are implemented at the ward level. From a state perspective this provides a geographic scale for which political and management structures already exist, i.e. a local councillor and official staff to oversee the participatory process, as well as a clear population group to target. However, wards are devised for electoral and managerial purposes rather than for citizen need. In Cape Town it is common that wards host a wide diversity of income- and ethnic-groups, and also frequently cut-across residential lines.

[Is the socio-economic diversity of Ward 71 typical?] Most of my wards have got that combination. So ward 69 ... it's Masiphumele which is deprived, then Noordboek which is up there [ie. wealthy] ... Most of my wards is like that [sic] [SubCouncilManager1]

Unlike more homogenous wards ... here we vary from incredibly wealthy people ... to tremendous poverty as you go lower down the slopes, with some squatters in between [ForumMember6-Environment]

The consequences of such demographically-mixed political spaces are discussed below. Socio-economically mixed wards are a dual-consequence of the existence of low-income (typically informal) areas in close proximity to Cape Town's wealthy suburbs, but also represent a form of political gerrymandering to ensure that the low-income vote-base (typically in support of the ANC) is distributed across multiple wards. While other scholars have noted the crucial role of "the social geography of the city" (Ballard et al 2007:277) in shaping the nature of localised participation processes, this has been understood in terms of the differences between wards, for example in terms of the style of participation (e.g. loudhailers to call meetings in disadvantaged wards compared to adverts in newspapers in more prosperous wards), rather than how differences within wards can disadvantage some members. It is unsurprising that using a scale devised for intermittent public participation via elections for ongoing public participation is likely to reproduce the same processes of exclusion that dominate elections.

You have a representative from the library who would request a budget for books, then you have another representative whose community are in survival mode. How do you compare the needs of an already well-established area and a very poor area? [ForumMember1-Health]

Socio-economic diversity within the ward results in problems of allocation and lack of consensus within the ward forum (discussed in more detail in subsequent sections). Buire (2011) demonstrates this using the example of a ward representative requesting funds for 
Christmas trees when others in the ward live without electricity or sanitation. In this context, who gets to function as the community voice is crucial. While obvious to analyse this elite capture as agency-based, the technical space of the electoral ward is also complicit. Rather than serving as a static backdrop or technical framework for governance, the geo-political space of the ward provides a structural means for entrenching (rather than transforming) preexisting inequality. In this case, reliance on spatial structures ultimately places the extremes of citizenship (i.e. the highly-educated wealthy and the poorly-educated indigent) within a shared (and supposedly) equal platform of governance without any provision of additional support to mediate such differences. Consequently the geopolitical space of the ward (in addition to the failings of the ward councillor and broader state structures) is complicit in prohibiting the ward forum from producing a participatory space that is just and inclusive. Stated in such terms, it is hardly surprising that an unequal urban space produces unequal citizenship, but the inability of state structures to mitigate this expected outcome is problematic.

Furthermore, reliance on the technical space of the ward as the context for public participation fails to meet citizens at the scale of their lives in two ways. Firstly, the boundaries of the electoral ward do not respect tacit suburban norms, and instead cut across everyday residential life, with neighbours sometimes in different wards; and secondly the size of the ward (incorporating multiple suburbs) extends beyond the scope of people's local citizenship, sometimes affecting ability to attend meetings. Essentially, the ward is a political unit that serves the state and not a space that citizens relate to in their everyday lives. This is particularly problematic for a participatory process that claims to 'listen to the people'.

The ward boundary is right in the middle of Bergvliet [a suburb in the ward] councillor $\mathrm{x}$ has this part of the suburb and councillor $\mathrm{y}$ has the other half. The suburb is split in half ... It probably doesn't mean much to political leaders, but it means a hell of a lot to communities. [ForumMember5-Sports]

Arguably the scale of the ward bears no resemblance to residents' perceptions of their everyday lives, and its use as a scale that represents local communities is therefore under question (Ballard et al, 2007). Indeed, there is increasing recognition that the scale of ward also irrelevant for the state in terms of legislative decision-making, where portfolios are thematic rather than geographic (Wafer, 2008; Benit-Gbaffou, 2008b; Piper and Deacon 2008). Wafer's (2008) research on the Soweto Electricity Crisis Committee condemns the utility of the ward scale, revealing it as a "scale without a compelling scalar narrative" (p111) in the sense that it represents neither the citizen scale of the neighbourhood nor the city scale of the municipality. Clearly a geopolitical spatial framework devised for electoral purposes is not relevant for ongoing participatory processes, yet debate on the structural limitations of space is remarkably absent.

A further way in which the spatial scale of public participation can entrench exclusion is via physical attendance at meetings. For forum members with access to a private car, the location of the meeting is unproblematic, but for the geographic ward forum member, the location of meetings outside his neighbourhood restricted his ability to represent his low-income community both in terms of his physical presence, but also in weakening other members' perception of him. 
I don't have transport so it's difficult for me to get there. Last time I walked after work, but this time the meeting is too far away - I don't know why they moved it [ForumMember3-Geographic]

We have one guy from Westlake but he arrived at the end of the last meeting - just as we were finishing he walked in! We barely had a quorum. [ForumMember2-Culture]

I don't even know who the person from Westlake is - they should be at the ward forum [ForumMember4-Ratepayer]

Although Forum Member 3 spoke to the councillor about his transport problems, the subcouncil at that time had no financial provision for meeting attendance or transport in getting to meetings. ${ }^{4}$ In order to resolve this problem, it was proposed by the councillor that the venue would move around the ward each month so that it would sometimes be a manageable walk (and obviously therefore it would sometimes be an unmanageable walk). This was agreed as an acceptable solution by all present forum members (Forum Member 3 was not present at this meeting), further indicating the ways in which reliance on a spatial structure that does not reflect citizens' own scales of everyday life, can entrench pre-existing marginalisation and weak capacity..

While the specific ward (or urban) scale is under-critiqued in existing literature, the role of the local scale has received attention. The decentralisation or localisation of democracy implies an assumption that the local is somehow a superior scale for bridging the gap between the state and its citizens (an assumption countered by Purcell, 2006), and furthermore, that the local scale has the potential to enable a citizen-led agenda. In fact, there is widespread evidence that the local provides a breeding ground for clientalism and corruption, in part facilitated by close relationships at the local scale (Benit-Gbaffou, 2011). Furthermore, as this case demonstrates, the 'local' scale itself does not always represent citizens' identities and interests, particularly when based on a spatial unit designed to serve the needs of representative rather than participatory democracy.

\section{Structural exclusion: temporal blindness}

Introducing a new space of public participation implies that pre-existing forms of participation and mobilisation are either absent or insufficient. While South Africa's ward forums acknowledge existing practices of collective citizenship (because forum members represent their 'sector' as members of a state-registered $\mathrm{CBO}$ ), the process assumes these sectors are neutral and non-political themes that can be represented altruistically. Institutionalising a new forum for pre-existing groups essentially seeks to depoliticise civil society by transforming politically-active citizens into 'clients' participating in supposedly non-political spaces of state-citizen engagement. While this makes it easier for the state to 'listen' to public voices, because citizens (or clients) are streamlined into state procedures, in doing so the participatory process effectively co-opts and/or usurps existing spaces of participation and mobilisation, consequently weakening the voice of civil society. Myopia (unwitting or otherwise) is consequently analysed below as a form of structural exclusion.

\footnotetext{
${ }^{4}$ Financial payment for transport has since been made available.
} 
South Africa has a long history of community activism and political mobilisation of the poor; in particular, township civic associations ('civics') were highly active in the anti-apartheid struggle, instigating township uprisings that proved apartheid's downfall (Seekings 1996). Thus, community-based leadership structures have long dominated politics in most lowincome communities (Heller 2003, Lanegran 1996), and although civic associations have struggled to re-assert their role in the post-apartheid context, they have played a crucial role at the community-scale. For many communities 'civics' remain the space identified as the leadership, representation and voice of the community, and in the contemporary era, many have re-emerged as Community Development Forums (CDFs) (Beall et al, 2002). Concurrently, Rate-Payer Associations (RPAs) are dominant in middle-class suburbs, providing a space for representation and communication between government and communities. However, the organisation of CDFs and RPAs and their capacity to negotiate their position against experts and elites is highly place-specific (Oldfield 2000). Given this history of political activism it is surprising that the new ward forum structure was effectively conceptualised in a myopic fashion. For whilst the institution of the forum explicitly acknowledges pre-existing groups (whereby the forum acts as the central point for existing groups to meet collectively) it simultaneously ignores both the multiplicity of groups per 'sector' as well as the politicisation of these groups. This institutional myopia has two significant consequences for the practice of citizenship.

Firstly, sector representatives unsurprisingly promote their interests, thereby creating unequal access to resources; and secondly, the separation of 'geographic' and 'sector' based representatives effectively creates a two-tier system of forum membership that entrenches privilege. While these outcomes can be explained by elite-capture, I argue that the institutional process surrounding the ward forum itself promotes two-tier citizenship by ignoring social and spatial history in its design. To explain, all interviewed ward forum members became involved in this participatory mechanism to promote the interests of a specific community-based group in which they had pre-existing membership (e.g. local library, sports club, environmental group, rate-payer association), rather than to engage with a broader vision of representative participation. Such self-promotion is hardly surprising, but the institutional process encourages this in two ways: firstly by allowing only one representative per sector, and secondly by creating a geographic alternative to sector representation that effectively maligns geographic representatives to second-rate citizens. Although ward forum members are elected to represent their sector or geographic area, interviewed forum members felt unqualified to represent a 'sector' they knew little about, and therefore used the forum to promote their own group-based interests.

There is only one representative per interest group [sector] ... I'm sports and culture but ... what groups exist? I don't know! I'm not their mouthpiece at all ... I'm trying to get money for my sports association. There might be a sports association in Retreat [poorer area] which needs the money more than us, but ... I don't have time for that ... There is money, so obviously I apply for my own body. [ForumMember5-Sports]

The ward forum idea is that one person represents his sector and the councillor sits on top and makes decisions. But that assumes that a volunteer will coordinate with their sectors, but why should they? [ForumMember4-Ratepayer]

These quotes highlight the way in which an institutional procedure promoting one 'representative' per sector in fact awards full citizenship to some at the expense of others. Although examples of elite capture and the opportunity cost of involvement are not new, the 
concern with this case is the institutionalisation of a process that was predicted in advance due to Cape Town's extreme inequality. According to the Mayor of Cape Town at the time of the ward forum's initial implementation, the ward forum (as opposed to a ward committee) explicitly included a larger number of members (both geographic and sector representatives) precisely to avoid these types of elite capture, yet this institutional approach has assumed a significant level of altruism, organisation and commitment on the part of forum members without adequate state support.

Ward forum's dual-membership of geographic and sector was devised to ensure that all citizens, whether organised into a registered $\mathrm{CBO}$ or not, could secure representation. However, it has ultimately resulted in the creation of two-tier citizenship. Geographic representatives require 35 signatories of support from within their geographic area (voting district), while sector representatives must demonstrate membership of a local CBO that has a legal constitution and minutes demonstrating regular meetings (the sub-council maintains a database of eligible CBOs). In effect this creates two types of forum members - those with long-standing involvement in formalised community activism who can use the forum as a platform to promote issues in relation to their $\mathrm{CBO}$, and those who have weak pre-existing capacity (i.e. no CBOs registered with the city) and can contribute only in relation to their (typically low-income) geographic area. The distinction between these two types of forum membership is even more extreme given that RPAs (common in wealthy suburbs) have their own 'sector', rather than being a geographic form of representation, but CDFs (typically found in low-income communities) do not. While this distinction is presumably because RPAs are registered CBOs, it results in a stark form of institutional inequality that is embedded in the design of the ward forum process. Indeed, the only 'geographic' member of the ward forum (and the only geographic representative within the sub-council) represents a very poor statesubsidised housing settlement.

The city put out a notice saying that they were setting up these ward forums ... And they called for people to be nominated to the forum, but you had to be nominated by a legal group ... There were special nomination forms and you had to have minutes from a body with a constitution, It was all very well controlled because they didn't want people jumping in with their own agendas ... It was a very strict process ... but it was worth it to ensure that you have representatives from groups that had some standing [ForumMember6-Environment]

Ward 71 is very wealthy suburbs, so Westlake said we want a people [sic] to represent our area. So he doesn't relate to his group [sector], he relates to his area. [SubCouncilManager1]

I can only speak on Westlake ... In meetings I am the only one who talks about Westlake. [ForumMember3-Geographic]

The quotes indicate a clear distinction in the rationale behind differential ward forum membership that is grounded in South Africa's history of socio-spatial inequality. While axiomatic that socio-economically and racially diverse political units in contemporary South Africa function within the legacies of apartheid's unequal social and spatial system (Oldfield, 2002), the entrenchment of historic inequality within the structural design of contemporary participation is problematic. Writing when Cape Town's participatory governance procedures were first proposed, both Pieterse (2002) and McEwan (2003) noted the potential for elite capture given the spatial and socio-economic inequalities entrenched in South Africa's urban 
spaces and social fabrics after decades of institutionalised apartheid. Indeed, McEwan (2003) specifically raised the problem of elite co-optation, whereby for low-income areas situated in close proximity to affluent suburbs, middle-class residents use their relatively greater education and expertise to control access to local resources, thereby diverting public funds to support their own interests and activities (e.g. golf clubs, horse riding). However, this is not merely a problem of elite capture, but related to the institutional process of public participation, and the inability of legislation to tackle the spatial and temporal scale of participation in the context of inequality.

Further, the only influence that ward forum members possess lies in requesting funds from the sub-council. Forum sector members, representing groups registered with the sub-council, can submit fully-budgeted proposals up to R100,000. Buire (2011:468) describes how these funds are perceived by communities as "pocket money" to alleviate short-term needs rather than as a long-term measure to address systemic need. However, geographic members, are restricted from applying for large grants because they do not represent a registered CBO. Consequently, instead of having their position strengthened by participating in the ward forum, geographic representatives (typically from low-income areas) are relegated to secondtier status.

[For] the ward allocation ... we received no guidelines, just an email saying we should submit an application ... I don't like that they expect us to understand everything. Don't presume that people doing a voluntary job know what a capital or operational budget is. [ForumMember4-Ratepayer]

The Westlake development forum doesn't have a non-profit number, so we can only apply for R10 000 [ForumMember3-Geographic]

While several forum members presented budgeted proposals for very large sums, the Westlake geographic representative was unable to participate in this process firstly, because the Westlake CDF is not a registered CBO, and secondly because of weak capacity to develop a budgeted proposal without additional support. Consequently the ward forum process itself (rather than its implementation or elite capture) entrenches pre-existing marginalisation and weak capacity. In this context the ward councillor has the potential to play a key role in mediating differential access to citizenship. While debates vary on the efficiency of the ward councillor, there is general consensus that the absence of legislative power accompanied by weak accountability creates a context where clientalism and patronage flourish (Benit-Gbaffou, 2008b; Buire, 2011). Indeed, in the case study ward, the councillor made it clear, both in interviews and his attitude during forum meetings, that he viewed the ward forum as unnecessary, preferring a personalised style of governance.

[How has the ward forum system altered your role?] It makes no difference whatsoever and it takes up time ... I find more value in approaching community groups directly for information. Most of the RPA meetings I attend ... I prefer not to attend the Westlake Development Forum because it's a very ANC vehicle ... If you want to raise a local issue then go directly to me as councillor and I will raise it at sub-council. [Ward councillor]

As the above quote indicates, public participatory processes are rarely politically neutral, with access to citizenship reliant on access to a politicised mediator (von Lieres and Piper, 2014), in this case the ward councillor as a representative of the local state. Given the failure of 
state-instituted participatory mechanisms to effectively enable low-income groups to participate, alongside widespread recognition that civil society groups have long existed within all types of communities, it would seem prudent for the state to harness pre-existing structures that are already functioning effectively within communities rather than create new mechanisms (McEwan, 2003), as well as supporting the emergence of community-based groups. Ideally this would function outside the boundaries of party politics, and therefore not be reliant on a political appointment such as a ward councillor. While Heller (2001) argues that a pre-condition for successful decentralised participatory democracy is the presence of a "well-developed civil society" (p139), he recognises that in South Africa particularly, the preexisting capacity of certain civil society groups (and in particular, their relative capacity in relation to other civil society groups) significantly limits the potential for participatory governance to be inclusive and to provide a voice for the marginalised.

\section{Two-tier citizenship: the role of the state}

The prior two sections have highlighted how a process of public participation that relies on the scale of the electoral ward, rather than citizens' own spaces, and is devised with little acknowledgement of historic mobilisation or capacity, , can privilege some at the expense of others. Examples from the case study ward forum highlighted how this new form of governance, that is transplanted on-top of existing inequalities and mobilisations, facilitates the creation of a two-tier citizenship that entrenches (rather than transforms) pre-existing spatial and social inequality.

The absence of temporal recognition by the state in establishing ward forums is crucial in enabling the promotion of some 'good' citizens over others. 'Good' in the sense that they fit the state's normative expectations of citizenship and therefore receive superior access to the benefits of participation. This sits in direct opposition to the recommendations of Hickey and Mohan (2004) for participation to be situated within a broad historical process of socioeconomic transformation. In other words, they argue that in order for participatory governance to bring about transformative social justice it cannot operate within a narrow locally- or project-based system, whereby citizens give opinions on specific places of projects, but needs to be part of a much wider radical political project that empowers people to transform their social context outside of the institutional structures in which participation is initiated. Such a radical approach to participatory governance, where participation involves challenging and confronting existing power structures (rather than forcing citizens to conform) is inevitably difficult for states to implement. However, if the Mayor of Cape Town's goal of inclusive citizenship is to be achieved, , then the forms of citizenship need to be defined by citizens rather than provided by the state.

Crucially, the ward form system provides zero mechanisms to challenge the structures within which it functions, instead serving as a tightly-controlled space for citizens who already fit the state's normative assumptions of 'good' citizenship (e.g. membership of a state-registered collective body and ability to attend regular meetings via private transportation) to promote their agenda. While this supposedly 'good' citizenship relies on an expectation of extreme altruism (ie. the state expects forum members to represent their sector), the reality is that it facilitates extreme selfishness. Rather than blame the agency of forum members, this paper has revealed the role of the state in creating a participatory space that, through its reliance on historically unequal spatial and temporal structures, actively creates a two-tier form of citizenship that further excludes the marginalised. 
The fact that the majority of South African citizens are new to their citizenship role is crucial, particularly when they are expected to function in shared participatory spaces with those for whom citizenship is deep-rooted. State-led processes of participatory governance expect certain behaviours from citizens, but do nothing to teach this to those without this sociopolitical expertise, and consequently a two-tier citizenship emerges. Those with pre-existing citizenship capacity, for example in interacting with public officials and presenting their needs as part of a CBO, continue to access high levels of citizenship rights in terms of access to resources and decision-making processes. However, those for whom citizenship is relatively new and therefore potentially have weak capacity to engage with public officials in a manner deemed appropriate by the state, for example because civic mobilisation has been framed around opposition rather than collaboration, can access only a limited version of the same citizenship rights.

\section{Conclusion}

Using a case study from contemporary urban South Africa, this paper has highlighted the role of the spatial and temporal urban landscape in mediating participatory governance. While prior critiques of participatory processes have focused on human agency problems of implementation alongside conceptual concerns related to structural power imbalance, research from Cape Town, a highly divided city, has revealed the non-neutral role of geopolitical and temporal structures in shaping participatory governance, and entrenching a twotier citizenship. This research has illuminated the ways in which South Africa's contemporary project to localise democracy fails to enable transformative participation, equal citizenship, or the creation of a just city because of its reliance on firstly, a geopolitical scale designed for intermittent rather than regular participation, and secondly, the institutional myopia the politicisation and capacity-differentials of existing practices of citizenship. This paper has looked beyond traditional concerns about elite capture and unequal power structures, to highlight the role played by institutional frameworks in facilitating the creation of a two-tier citizenship. This is particularly pertinent given Pieterse's (2002:3) decade-old demand that participatory governance processes "must be rooted in a sober understanding of the history of urban politics (formal and informal), [and] the spatiality of urban development policies (how actions impact on the urban system and form)". South Africa's democracy is dependent on equal citizenship for all, yet as this case highlights, this constitutional right has not been translated into reality at the grassroots level. 


\section{References}

Ballard, R., Bonnin, D., Robinson, J. and Xaba, T., 2007, 'Development and new forms of democracy in eThekwini', Urban Forum, 18, pp265-287.

Beall, J., Crankshaw, O. and Parnell S., 2002, Uniting a Divided City, Earthscan, London.

Benit-Gbaffou, C.. 2008a, 'Introduction: The place of participation in South African local democracy', Transformation: Critical perspectives on southern Africa, 66/67, ppi-vii

Benit-Gbaffou, C.. 2008b, 'Are practices of local participation sidelining the institutional participatory channels? Reflections from Johannesburg', Transformation: Critical perspectives on southern Africa, 66/67, pp1-33

Benit-Gbaffou, C., 2011, "Up Close and Personal' - How does local democracy help the poor access the state? Stories of accountability and clientalism in Johannesburg', Journal of Asian and African Studies, 46(5), pp453-464.

Benit-Gbaffou, C. and Oldfield, S., 2011, 'Accessing the State: Everyday Practices and Politics in Cities of the South', Journal of Asian and African Studies, 46(5), pp445-452.

Buire, C., 2011, "Bringing government closer to the people'? The daily experience of subcouncils in Cape Town', Journal of Asian and African Studies, 46(5), pp465-478.

Cape Argus, 2006, 'City is not delaying but 'looking for alternatives' to ward committees', Cape Argus, 11 September.

Cape Argus, 2013, 'Ward Committee's failure to launch City Struggles', 6 March.

Cape Times, 2007, 'City to go it alone with ward forums, despite Dyanti', Cape Times, 19 July.

Coelho, V.S. and Favareto, A., 2011, 'Participatory governance and development: in search of a causal nexus', Geography Compass 5(11), pp641-654.

Cooke, B., and Kothari, U., 2001, Participation: The New Tyranny, Zed Books: London.

Cornwall, A., 2000, Beneficiary, Consumer, Citizen: Perspectives on Participation for Poverty Reduction (Gothenburg: Sida Studies).

Cornwall, A., 2004a, 'Spaces for Transformation? Reflections on Issues of Power and Difference in Participation in Development', in: S. Hickey and G. Mohan (eds), Participation: From Tyranny to Transformation? Exploring New Approaches to Participation in Development, London and New York: Zed Books.

Cornwall, A., 2004b, 'Introduction: New Democratic Spaces? The politics and dynamics of institutionalised participation', IDS Bulletin, 35(2), pp1-10. 
Department of Provincial and Local Government (DPLG), 2005, Ward Committee Resource Book, DPLG, South Africa,

http://www.capegateway.gov.za/Text/2006/2/ward_committee_resource_book.pdf

Harpham, T. and Boatang, K.A., 1997, 'Urban governance in relation to the operation of urban services in developing countries', Habitat International, 21.2, pp Pages 65-77

Heller, P., 2001, 'Moving the state: the politics of democratic decentralisation in Kerela, South Africa and Porto Alegre', Politics and Society 29, pp131-163.

Heller P., 2003, 'Reclaiming democratic space: civics and politics in post-transition Johannesburg', in Tomlinson R., Beauregard, R.A., Bremner, L. and Mangu, X., Emerging Johannesburg: perspectives on the post-apartheid city. London: Routledge, pp155-184.

Hickey, S. and Mohan, G., 2004, Participation: from tyranny to transformation, Zed Books: London.

Jessop, B., 2001, 'Governance failure' in Stoker, G. (ed.), The New Politics of British Local Governance, London, Macmillan.

Lanegran K., 1996, 'South Africa's Civic Association Movement: ANC's ally or society's 'watchdog'? Shifting movement-political party relations', Critical Sociology, 22(3).

Lemanski, C. and Marx, C. (Eds.), 2015, The City in Urban Poverty, Palgrave-Macmillan.

McEwan, C., 2003, "Bringing government to the people': women, local governance and community participation in South Africa', Geoforum 34, pp469-481,

Miraftab, F., 2004, 'Invited and Invented Spaces of Participation: Neoliberal Citizenship and Feminists' Expanded Notion of Politics' Wagadu 1 1-7

Oldfield, S., 2000, 'The centrality of community capacity in state low-income housing provision in Cape Town, South Africa', International Journal of Urban and Regional Research, 24(4), pp858-872.

Oldfield, S., 2002, 'Local state restructuring and urban transformation in post-apartheid Cape Town', GeoJournal, 57, pp39-47.

Parnell, S., Pieterse, E., Swilling, M. and Wooldridge, D. (Eds.) (2002) Democratising Local Government: the South African Experiment, University of Cape Town Press

Parnell, S. and Oldfield, S., 2014, The Routledge Handbook of Cities of the Global South, Abingdon, Routledge.

Pieterse, E., 2002, 'From divided to integrated city? Critical overview of the emerging metropolitan governance system in Cape Town, Urban Forum, 13 (1), pp3-37. 
Piper, L. and Deacon, R., 2008, 'Partisan ward committees, elite accountability and community participation: the Msunduzi case', Critical Dialogue, 4(1), pp 41-46.

Purcell, M., 2006, 'Urban Democracy and the Local Trap', Urban Studies, 43(11), pp19211941.

Republic of South Africa (RSA), 1996, Constitution of the Republic of South Africa, Pretoria.

Seekings, J., 1996, 'The Decline of South Africa's Civic Organizations, 1990-1996', Critical Sociology, 22.3, pp135-157.

Sinwell, L., 2010, 'Conceptualising direct action as a form of participation in development: a South African case', Politikon, 37(1), pp67-83.

Swyngedouw, E. 2005, 'Governance innovation and the citizen: the Janus face of governance beyond the state", Urban Studies 42, pp1991-2006

UNCHS, 2000, 'UNCHS (Habitat) - the global campaign for good urban governance', Environment and Urbanisation, 11(2), pp197-202.

von Lieres, B. and Piper, L. (Eds.), 2014, Mediated Citizenship: the informal politics of speaking for citizens in the global South, Palgrave-Macmillan, London.

Wafer, A., 2008, 'Scale and identity in post-apartheid Soweto', Transformation: Critical perspectives on southern Africa, 66/67, pp98-115

Williams, G., 2004, 'Evaluating Participatory Development: tyranny, power and (re)politicisation', Third World Quarterly 25(3), 557-579

Zille, H., 2007, 'City wants more public engagement', Cape Argus, 2 August. 